\title{
キナソロン環を含むエポキシ 樹脂の合成と性質
}

(昭 和 45 年 4 月 30 日受理)

西崎 俊一郎・森 脇 紀 元 $^{* 1}$

熱安定性のすぐれたェポキシ樹脂をつる目的で，キナゾロン環を主鎖に導入したェポキシ化合物を合成し，その硬化物の性質を

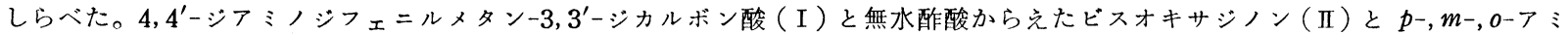
ノフェノールからビスキナゾロンフェノール(III)を合成し, ついでェピクロルヒドリンとの反応でビスキナゾロンェポキシ化合物 （N）をえた。これらは $129 \sim 142^{\circ} \mathrm{C}$ の $\mathrm{mp}$ をち, 有機溶媒に可溶で, ビスフェノール A グリシジェ一テルなどと相溶性をも つ。酸無水物による硬化物の電気的性質, 機械的強度, 熱的性質についてしらべ, $T_{\mathrm{g}}$ は $200^{\circ} \mathrm{C}$ 以上にぬり, オルソ, メタ, パラ 体の順に $T_{\mathrm{g}}$, 熱安定性の高いことをみとめた。

\section{1 緒 言}

芳香族複素環を主鎖に薄入したポリマーは熱的に安定であり， ポリイミド, ポリベンズイミダゾールなど閉環縮合法によって合 成されたポリマーがよく知られている。

また，末端にエポキシ基を有するポリマーはすぐれた加工性， 物理的強度, 電気的性質などから広い応用面をもっているが，複 素環を主鎖にもつ末端エポキシ樹脂の合成，性質など詳細は知ら れていない。イミド環を含むエポキシ化合物の合成の著者らの試 みでは, その難溶性, 高融点から得られたものは不満足なもので あった1)。

著者らはさきにキナゾロン環を含むポリマーは比較的溶解性に とみ，しかも熱安定性のすぐれていることをみとめた2)ので，こ れらキナゾロン環を含むエポキシ化合物の合成を試み, その硬化 樹脂の性質について一，二の知見を得たので報告する。

ポリキナゾロンの合成は, Serlin ら³)がジアミノテレフタル酸 から得たベンッジメチルオキサジンと $4,4^{\prime}$-ジアミノジフェニル エーテルの反応よりえたものが初めてであり, その後, Gandemaris $5^{4,5)}$, 庄野ら ${ }^{6)}$ によって研究が行なわれた。

著者らは, $4,4^{\prime}$-ジアミノジフェニルメタン $-3,3^{\prime}$-ジカルボン酸 （I）と無水眽酸からビスオキサジノン（II）をえて，II とアミノ フェノールからビスキナゾロンフェノール(III)を合成し, ついで このものとエピクロルヒドリンの反応によってビスキナゾロンエ ポキシ化合物 $(\mathrm{V})$ をえた。生成エポキシ化合物と酸無水物から硬 化樹脂をえて, 熱的性質, 機械的強度, 電気的性質の二, 三につ いてしらべた。<smiles>Nc1ccc(Cc2ccc(N)c(C(=O)O)c2)cc1C(=O)O</smiles>

*1 Shiunichiro NISHIZAKI, Toshimoto MORIWAKI 三菱電 機株式会社中央研究所: 尼崎方南清水字中野.

1）西崎俊一郎，森脇紀元，未発表.

2）西崎俊一郎, 不可三 晃, 工化, 73, 1239 (1970).

3) I. Serlin, A. H. Markhart, J.Polym.Sci., 60, S 59(1962).

4) G. deGandemaris, B.Sillon, J.Prévé, Bull. Soc. Chim. France, 1965, 171.

5) G. deGandemaris, B. Sillon, J. Polym. Sci., C 22, 827 (1969).

6）庄野利之, 八浜元和, 山庄司由子, 新良宏一郎, 日本化学 会第 21 年会予稿集, 4, 2728 (1968).

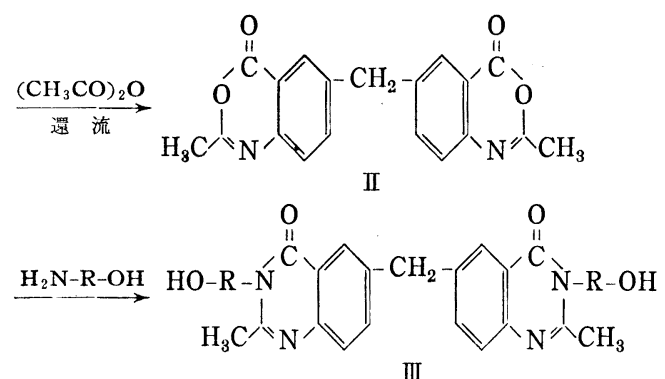

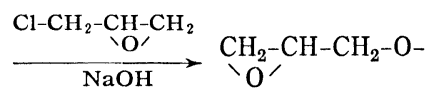

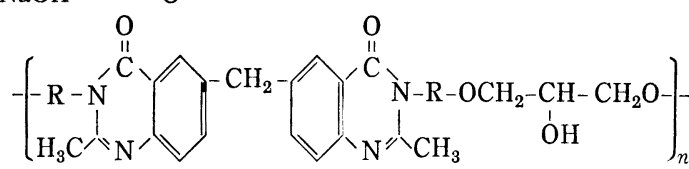<smiles></smiles>

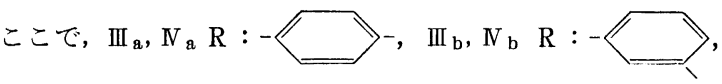<smiles>[R]C1=CC=C2CC1CC2[Y17]</smiles>

\section{2 実験}

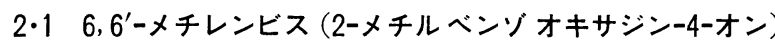
(II) の合成

$4,4^{\prime}$-ジアミノジフェニルメタン $-3,3^{\prime}$-ジカルボン酸( I ) (イハ ラケミカル製, $\left.\mathrm{mp} 233 \sim 235^{\circ} \mathrm{C}\right) 200 \mathrm{~g}$ に $1 l$ の無水酢酸を加兄, 8 時間還流したのち, 結晶を口過し, 無水酢酸で十分洗浄した。 ジメチルアセトアミド (DMAc) から再結晶し，淡黄色の結晶を

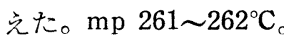

分析値 C : $67.96 \%, \mathrm{H}: 4.19 \%, \mathrm{~N}: 8.51 \%$

$\mathrm{C}_{19} \mathrm{H}_{14} \mathrm{O}_{4} \mathrm{~N}_{2}$ として計算値

$$
\text { C : } 68.26 \%, \mathrm{H}: 4.22 \%, \mathrm{~N}: 8.38 \%
$$

$2 \cdot 2$ ビスキナソロロフェノール (III) の合成

ビスオキサジノン (II) $33.4 \mathrm{~g}(0.10 \mathrm{~mol})$ と $p$-アミノフェノ ール (市販品, $\left.\mathrm{mp} 185 \sim 186^{\circ} \mathrm{C}\right) 25 \mathrm{~g}(0.23 \mathrm{~mol})$ とを $m$ ークレゾ ール $150 \mathrm{~g}$ にとかし加熱還流寸る。3 時間反応後, 生成物をエー テル中にそそぎ込み沈殿を生じさせ，口過後，アルコールで過剩 のアミノフェノールを十分洗い, 減圧乾燥して $\mathrm{III}_{\mathrm{a}}$ をえた。 
mp $215^{\circ} \mathrm{C}$, 収量 $49 \mathrm{~g}$ （II 飞対し収率 $94.9 \%$ ) で，IR スペク トルは, $\mathrm{OH}$ が $3400 \mathrm{~cm}^{-1}$ に，キナジロン環の $\nu_{\mathrm{C}=0}$ は 1670 $\mathrm{cm}^{-1}$ に市らわれた。

分析值 $\mathrm{C}: 71.74, \mathrm{H}: 4.62 \%, \mathrm{~N}: 10.53 \%$

$\mathrm{C}_{31} \mathrm{H}_{24} \mathrm{O}_{4} \mathrm{~N}_{4}$ として計算值

C $: 72.08 \%, \mathrm{H}: 4.68 \%, \mathrm{~N}: 10.84 \%$

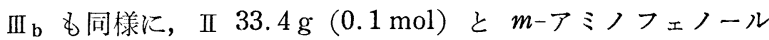

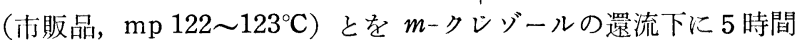
反応し，上述と同じく処理して， III ${ }_{\mathrm{b}} 50.6 \mathrm{~g}$ (収率 $98.0 \%$ ) を兄 た。

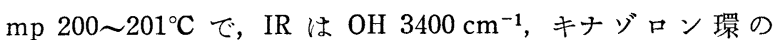
$\nu_{\mathrm{C}=0} 1672 \mathrm{~cm}^{-1}$ をみとめた。

分析值 $\mathrm{C}: 71.81 \%, \mathrm{H}: 4.80 \%, \mathrm{~N}: 10.41 \%$

$\mathrm{C}_{31} \mathrm{H}_{24} \mathrm{O}_{4} \mathrm{~N}_{4}$ として計算值

$\mathrm{C}: 72.08 \%, \mathrm{H}: 4.68 \%, \mathrm{~N}: 10.84 \%$

III $\mathrm{c}$ も同様に, II $33.4 \mathrm{~g}(0.1 \mathrm{~mol})$ とo-アミノフェノール(市

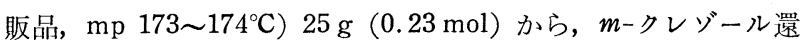
流下に 3 時間反応させてえた。収量 $48.3 \mathrm{~g}$ (収率 $93.6 \%$ ), $\mathrm{mp}$ $204 \sim 206^{\circ} \mathrm{C}$ で, IR は OH $3400 \mathrm{~cm}^{-1}$, キナゾロン環 $\nu_{\mathrm{C}=0} 1670$ $\mathrm{cm}^{-1}$ をみとめた。

分析值 $\mathrm{C}: 71.55 \%, \mathrm{H}: 4.81 \%, \mathrm{~N}: 10.35 \%$

$\mathrm{C}_{31} \mathrm{H}_{24} \mathrm{O}_{4} \mathrm{~N}_{4}$ として計算值

C $: 72.08 \%, \quad H: 4.68 \%, \quad N: 10.84 \%$

$2 \cdot 3$ ビスキナソロンエポキシ化合物 $\mathbf{I V}_{\mathrm{a}}, \mathbf{I V} \mathrm{b}, \mathbf{I V}_{\mathrm{c}}$ の合成

ビスキナゾロソフェノール $\mathrm{II}_{\mathrm{a}} 38.7 \mathrm{~g}(0.075 \mathrm{~mol})$ にェピク ロルヒドリン $92.5 \mathrm{~g}(1.0 \mathrm{~mol})$, 水 $2 \mathrm{~m} l$ を加えて $80^{\circ} \mathrm{C}$ に加熱 し，水酸化ナトリウム $6 \mathrm{~g}(0.15 \mathrm{~mol})$ を徐々に加兄，反応温度 を $90^{\circ} \mathrm{C}$ 以下に保ち，発熱反応が終わるまでかきまぜる。生成物 はエーテル中にそそぎこみ，沈殿を析出させ，口過後，水洗をく りか兄し, 減圧乾燥する。桃色粉末状 $\mathrm{N}_{\mathrm{a}}$ を $40.3 \mathrm{~g}$ (収率 $\mathrm{III}_{\mathrm{a}}$ に対し $85.2 \%$ )を得る。融点 $140 \sim 142^{\circ} \mathrm{C}$, IR はエポキシ環 ( $\left.\nu_{\mathrm{C}-\mathrm{O}-\mathrm{C}}\right) 909 \mathrm{~cm}^{-1}$ ，キナゾロン環 $\nu_{\mathrm{C}=\mathrm{O}} 1672 \mathrm{~cm}^{-1}$ を示した。

分析值 C: $69.35 \%, \mathrm{H}: 5.20 \%, \mathrm{~N}: 8.02 \%, \mathrm{Cl}: 0.17 \%$, エポキシ当量 326

$\mathrm{N}_{\mathrm{b}}$ は， $\mathrm{II}_{\mathrm{b}}$ とエピクロルヒドリンから同様の方法で得ること

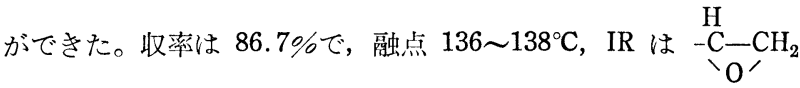
$910 \mathrm{~cm}^{-1}$, キナゾロン $1675 \mathrm{~cm}^{-1}$ を示した。

分析值 $\mathrm{C}: 69.47 \%, \mathrm{H}: 5.31 \%, \mathrm{~N}: 8.05 \%, \mathrm{Cl}: 0.23 \%$, エポキシ当量 330

$\mathrm{N}_{\mathrm{c}}$ も $\mathrm{III}_{\mathrm{c}}$ とエピクロルヒドリンとから, 上記と同様方法でえ た。収率は $82.5 \%, \mathrm{mp} 129 \sim 131^{\circ} \mathrm{C}, \mathrm{IR}$ は土ポキシ環 $\left(\nu_{\mathrm{C}-\mathrm{O}-\mathrm{C}}\right)$ $909 \mathrm{~cm}^{-1}$, キナゾロン鲌 $\left(\nu_{\mathrm{C}=0}\right) 1637 \mathrm{~cm}^{-1}$ を示した。

分析值 C: $69.53 \%, \mathrm{H}: 5.10 \%, \mathrm{~N}: 8.03 \%, \mathrm{Cl}: 0.27 \%$, エポキシ当量 333

$2 \cdot 4$ ビスキナゾロンエポキシ化合物 $\mathbf{I V}_{\mathrm{a}}, \mathbf{I V}_{\mathrm{b}}, \mathbf{I V}_{\mathrm{c}}$ の硬化

$\mathrm{N}_{\mathrm{a}}, \mathrm{N}_{\mathrm{b}}, \mathrm{N}_{\mathrm{c}}$ および比較のため, ビスフェノール A-ジグリシ ジルェーテル Epon 828 (Shell Chem 製) を無水メチルナジック 酸（MNA）により硬化した。硬化剂の配合はいずれのエポキシ 樹脂に対しても，エポキシ環 $1 \mathrm{~mol}$ 当量につき, $0.8 \mathrm{~mol}$ の MNA を用い゙また助触媒としてベンジルジメチルアミン (BDMA) の 0.5 重量\%を加光た。フィルムは上部混合物のクロロホルム溶液

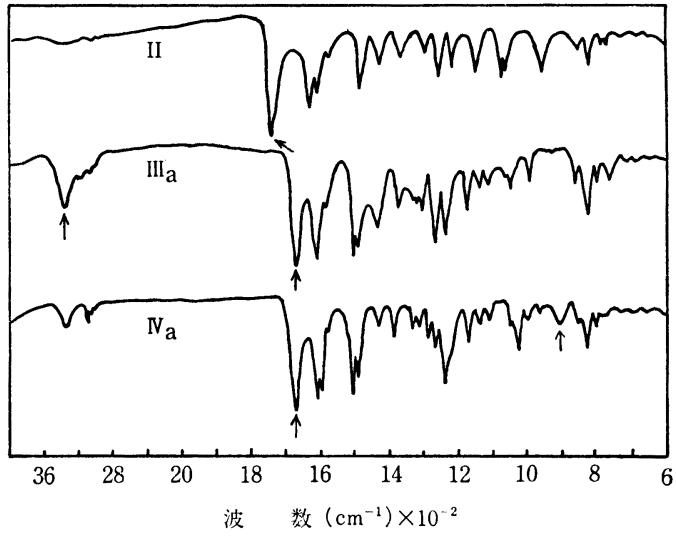

図 1 キナゾロン誘導体の $\mathrm{IR}$ スペクトル $(\mathrm{KBr}$ 錠剤 $)$

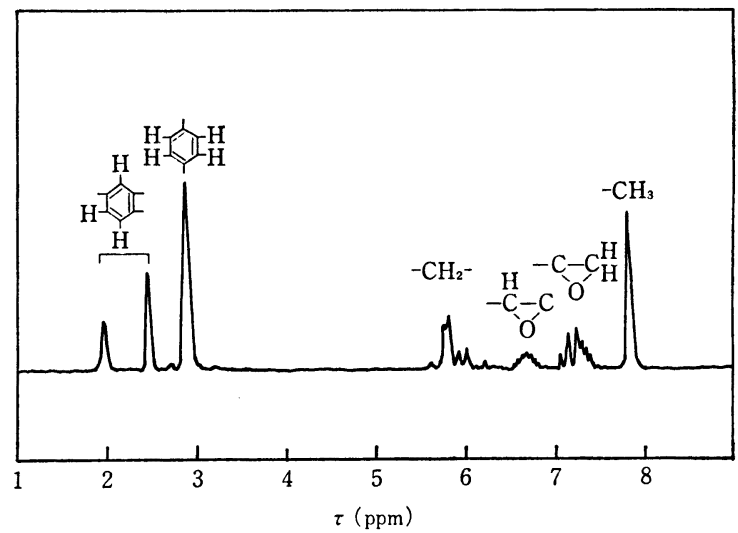

図 2 キナゾロンェポキシ化合物 $\mathrm{N}_{\mathrm{a}}$ の NMR スペクトル $\left(\mathrm{CDCl}_{3} 10 \%\right.$ 溶液, $\left.60 \mathrm{MHz}\right)$

から，2４ 回重社塗りで, $130^{\circ} \mathrm{C}, 2$ 時問，ついで $200^{\circ} \mathrm{C}, 12$ 時 間硬化を行なった。

\section{5 熱 分 析}

$\mathrm{N}$ の酸無水物による硬化樹脂の厚さ $0.1 \mathrm{~mm}$ のフィルム試料 について熱重量分析 (TGA), 差動熱量分析 (DSC) を窒素気流中 で行なった。TGA は島津 TGA-20 型, 試料量 $10 \mathrm{mg}$, 昇温速 度 $\Delta T=5^{\circ} \mathrm{C} / \mathrm{min}$ で行なった。DSC は Perkin Elmer DSC-1 型, 試料量 $15 \mathrm{mg}$, 昨温速度 $\Delta T=40^{\circ} \mathrm{C} / \mathrm{min}$ で行なった。

\section{$2 \cdot 6$ 電気的性㬏}

N の硬化物の電気的性質は誘電率 $(\varepsilon)$, 誘電体損失 $(\tan \delta)$, 体積固有抵抗 $\left(\rho_{\mathrm{V}}\right)$ を測定した。 $\varepsilon, \tan \delta$ はシェリングブリッジ 法（横河製 BVI-10 B 型）により，60 Hz，200 V で， $\rho_{\mathrm{V}}$ は直流 増幅法（タケダ理研， TR-4 型）により $100 \mathrm{~V}$ で測定した。試 料厚さは $0.1 \mathrm{~mm}$ で, 室温から $200^{\circ} \mathrm{C}$ までの範曲で, 空気恒温 槽中で行なった。

\section{$2 \cdot 7$ 機械的性質}

$\mathrm{N}$ の硬化物の引張り強さ, 伸び, 弾性率の強度依存性は, 島津

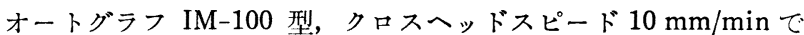
測定した。動的弾性率は東洋測器製バイブロンで, 周波数 $110 \mathrm{~Hz}$ で測定した。試片はいずれも $0.1 \mathrm{~mm}$ 厚さのフィルムを用いた。

\section{3 結 果と考察}

$3 \cdot 1$ ビスキナゾロンエポキシ化合物の生成

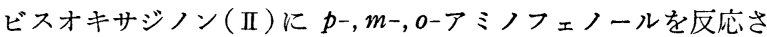


せ，それぞれ刘応するビスキナゾロンフェノール $\mathrm{II}_{\mathrm{a}}, \mathrm{II}_{\mathrm{b}}, \mathrm{III}_{\mathrm{c}}$ を 収量よくえた。これらの融点は meta $<$ ortho $<$ para 誘導体の順 に高くなっている。III の IR スペクトルはいずれも, $3400 \mathrm{~cm}^{-1}$ にフェノール性 $\mathrm{OH}, 1670 \mathrm{~cm}^{-1}$ にキナジロン環ケトン $\left(\nu_{\mathrm{C}=0}\right)$ の吸収がみとめられ，また元素分析值から吕はキナゾロンフェ， ールであることが確認できる。

III とエピクロルヒドリンの反応生成物 N は, IR スペクトルで エポキシ環による吸収が $910 \mathrm{~cm}^{-1}$ 付近に, キナゾロン環カルボ ニルによる吸収が $1670 \mathrm{~cm}^{-1}$ にみとめられ，また NMR スペク トルでは $\mathrm{N}_{\mathrm{a}}$ の場合, $\tau=1.94,2.45,2.90 \mathrm{ppm}$ にベンゼン環 プロトン, $\tau=5.77 \mathrm{ppm}$ 付近にメチレンプロトンが, $\tau=6.67$ $\mathrm{ppm}$ にエポキシ環メチンプロトン， $\tau=7.07,7.23 \mathrm{ppm}$ にエポ キシ環メチレンプロトン， $\tau=7.80 \mathrm{ppm}$ にメチルプロトン(キナ ゾロン環）に帰属されるピークの存在とそのプロトン強度比から, キナゾロンエポキシ $\mathrm{N}$ の生成が推定できる。しかし， $\mathrm{N}_{\mathrm{a}}$ の NMR スペクトルのよ5に $\tau=5.60 \mathrm{ppm}$ のメチレンプロトン, $\tau=6.21$ $\mathrm{ppm}$ の $\mathrm{OH}$ による弱いピークの存在, またエポキシ当量実測值 が，理論值 314 （（1 式 $\mathrm{N}$ で $n=0$ とした）より高く 326〜333 の值を示すことから， $\mathrm{N}$ は $n>0$ 成分を含むことが考皇られる。 エポキシ当量からの計算では, $N_{\mathrm{a}}$ で $n=0.042, \mathrm{~N}_{\mathrm{b}}$ で $n=0.056$, $\mathrm{N}_{\mathrm{c}}$ で $n=0.066$ となる。

元素分析で示される微量の塩素は未閉環 1,3-クロロヒドリン 基の微量の存在の可能性も示す。

ビスキナゾロンェポキシ化合物 $\mathrm{N}_{\mathrm{a}}, \mathrm{N}_{\mathrm{b}}, \mathrm{N}_{\mathrm{c}}$ はいずれも固体で あり, 融解軟化し始める温度は $129 \sim 142^{\circ} \mathrm{C}$ で, ビスフェノール A ジグリシジルェーテルにくらべて高い。有機溶媒に対する溶解 性は表 1 に示すように，パラ体くメタ体くオルソ体の順に溶解し やすい。また極性溶媒の注うが，非極性溶媒よりよくとけること がわかる。イミドのような複素環構造をもつものは, その rigid な構造から溶解性に乏しいが，キナゾロンエポキシ化合物では, メチルキナゾロン環, グリシジルエーテルなどの寄与によって溶 解性がイミドなどより大きい。

表 1 ビスキナゾロンェポキシ化合物 $\mathrm{N}$ の溶解性

\begin{tabular}{|c|c|c|c|}
\hline & $\mathrm{IV}_{\mathrm{a}}$ & $\mathrm{IV}_{\mathrm{b}}$ & $\mathrm{IV}_{\mathrm{c}}$ \\
\hline メタノ $-ル$ & - & + & H \\
\hline$x-$ テ & - & - & - \\
\hline $\boldsymbol{r} ト$ ン & - & + & H \\
\hline 酢酸メチル & - & + & + \\
\hline クロロホルム & H & H & $H$ \\
\hline 四塩化炭素 & - & - & - \\
\hline ピリ シ ン & H & H & $H$ \\
\hline$m$ ークレジール & H & H & H \\
\hline ジメチルアセトアミド & H & H & $H$ \\
\hline$N$-メチルピロリドン & $H$ & H & $H$ \\
\hline
\end{tabular}

溶剂 100 に対し、エポキシIV 10 を溶解する.

H: 室温で溶解, +：加熱すれば溶解, 一：不溶

また, 市販エポキシ樹脂, ビスフェノールAグリシジルェーテ ルや脂環式エポキシ樹脂との相溶性についてしらべた。後者のチ ッソノックス 221 (チッソ(株)製, 3,4-エポキシシクロヘキシル メチル-3,4-エポキシシクロヘキサンカルボキシレート)と $N_{\mathrm{b}}$ の 混合物では任意の割合で室温ですぐに溶解するが，前者の Epon 828 と $N_{b}$ は, 室温では 2〜3 時間を要し, 加温すればすぐに 相溶する。

\section{$3 \cdot 2$ ビスキナソロンエポキシ硬化樹脂の性筫}

ビスキナゾロンエポキシ化合物 $\mathrm{N}$ の無水メチルナジック酸によ

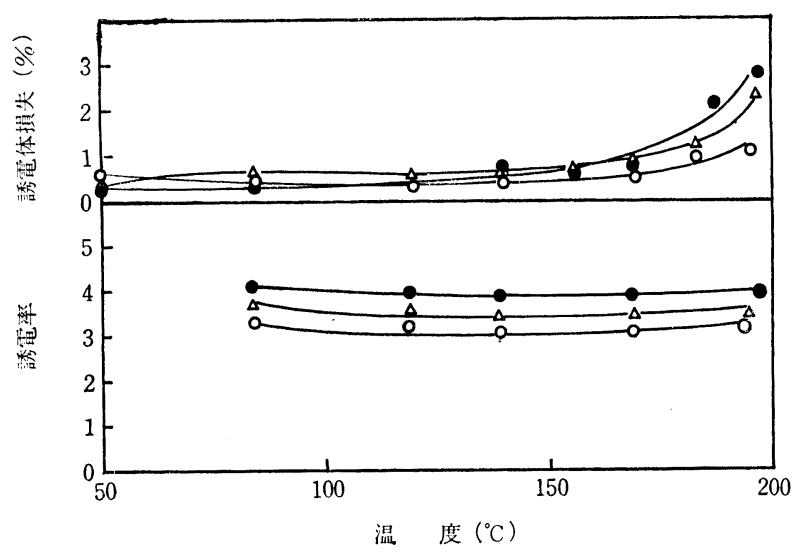

図 3 キナゾロンェポキシ樹脂硬化物の誘電率, 誘電体損失 $\mathrm{O}: \mathrm{IV}_{\mathrm{a}}-\mathrm{MNA}, \bullet: \mathrm{IV}_{\mathrm{b}}-\mathrm{MNA}, \triangle: \mathrm{I}_{\mathrm{c}}-\mathrm{MNA}$

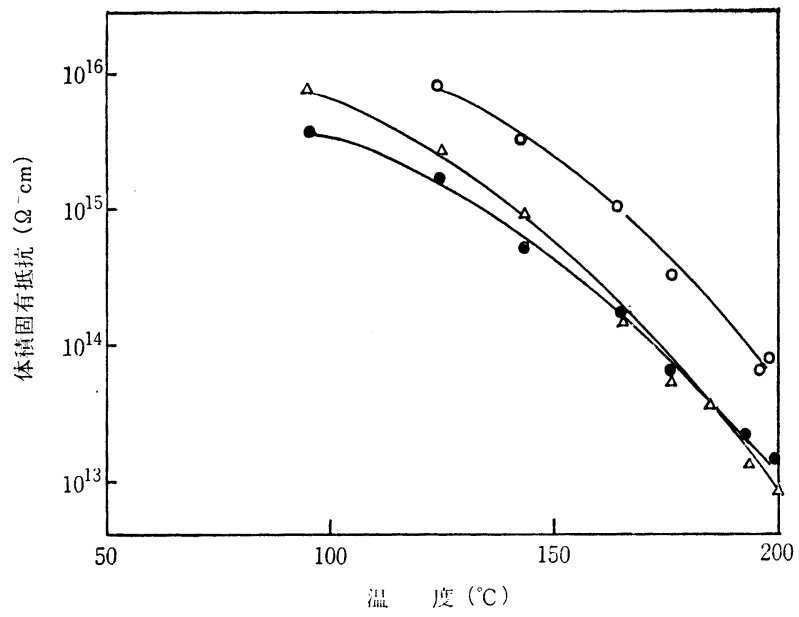

困 4 キナゾロンェポキシ樹脂硬化物の電気抵抗の温度 依存性

$\mathrm{O}: \mathrm{IN}_{\mathrm{a}}-\mathrm{MNA}, \bullet: \mathrm{IV}_{\mathrm{b}}-\mathrm{MNA}, \triangle: \mathrm{IN}_{\mathrm{c}}-\mathrm{MNA}$

る硬化樹脂の電気的性質, 誘電率 $(\varepsilon)$, 誘電体損失 $(\tan \delta)$ の温 度特性を図 3 に, 体積固有抵抗 $\left(\rho_{\mathrm{V}}\right)$ の温度特性を図 4 に示した。 $\mathrm{N}_{\mathrm{a}}, \mathrm{N}_{\mathrm{b}}, \mathrm{N}_{\mathrm{c}}$ 硬化物の $\varepsilon$ はいずれも3〜4 の範囲で $200^{\circ} \mathrm{C}$ ま で変化はみとめられない。 $\tan \delta$ は $170^{\circ} \mathrm{C}$ 付近からわずかに増加 し, $200^{\circ} \mathrm{C}$ で $\mathrm{N}_{\mathrm{b}}, \mathrm{N}_{\mathrm{c}}$ で $3 \%$ 近くの值, パラ構造の $\mathrm{N}_{\mathrm{a}}$ は約 $1 \%$ に達し, Epon 828-MNA 硬化物で見られる 100 110 ${ }^{\circ} \mathrm{C} の$ $\tan \delta$ の極大点は, $\mathrm{N}-\mathrm{MNA}$ 硬化物系では $200^{\circ} \mathrm{C}$ までには存在 しない。

キナゾロンエポキシ化合物 $\mathrm{N}-\mathrm{MNA}$ 硬化物の窒温に掠ける引 張り強さは表 2 に示した。また, 引張り弾性率の温度特性は図 5 に示した。弾性率の急激な低下は $200^{\circ} \mathrm{C}$ 以上で始まるが，これか ら求めたガラス転移温度 $T_{\mathrm{g}}$ は $\mathrm{N}_{\mathrm{a}} 215^{\circ} \mathrm{C}, \mathrm{N}_{\mathrm{b}} 207^{\circ} \mathrm{C}, \mathrm{V}_{\mathrm{c}} 205^{\circ} \mathrm{C}$ で, 主鎖のビスキナゾロンフェノールの構造がパラ, メタ, オル ソ体の順に低くなっていることを示している。

ビスフェノールAジグリシジルェーテル (Epon 828) とキナゾ ロンエポキシ化合物 $\mathrm{N}_{\mathrm{b}}$ の混合系を MNA で硬化したものの動

表 2 キナゾロンェポキシ樹脂硬化物の引張り強さ

\begin{tabular}{|c|c|c|c|}
\hline 硬 化 物 & $\begin{array}{l}\text { 引張り強ざ } \\
\left(\mathrm{kg} / \mathrm{mm}^{2}\right)\end{array}$ & 伸 $(\%)$ & $\begin{array}{l}\text { 引張り弾性率 } \\
(\text { yne } \\
\left.\mathrm{cm}^{2}\right)\end{array}$ \\
\hline $\mathrm{IV}_{\mathrm{a}}-\mathrm{MNA}$ & 9.8 & 4.5 & $2.6 \times 10^{10}$ \\
\hline $\mathrm{IN}_{\mathrm{b}}-\mathrm{MNA}$ & 11.3 & 5.0 & $2.3 \times 10^{10}$ \\
\hline $\mathrm{IV}_{\mathrm{c}}-\mathrm{MNA}$ & 6.8 & 4.5 & $2.4 \times 10^{10}$ \\
\hline
\end{tabular}




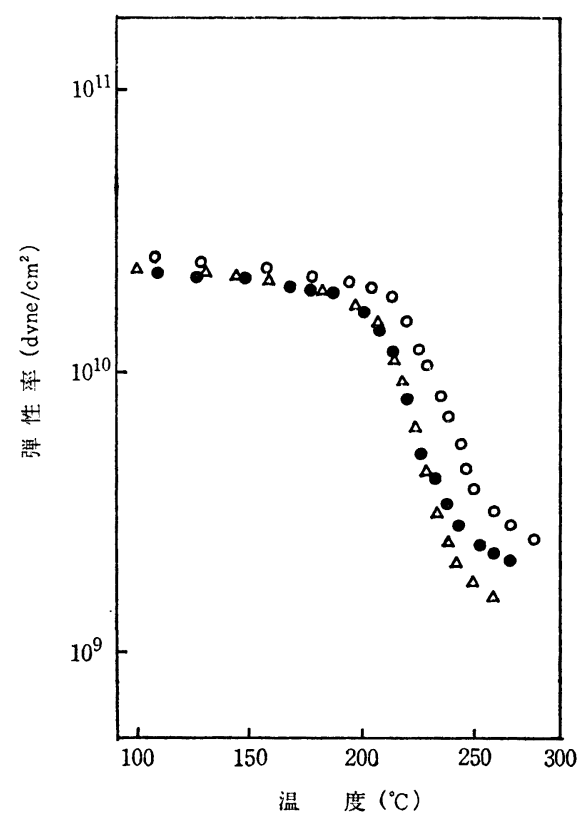

図 5 キナゾロンェポキシ樹脂硬化物の引張り弾性率 $\mathrm{O}: \mathrm{I}_{\mathrm{a}}-\mathrm{MNA}, \bullet: \mathrm{N}_{\mathrm{b}}-\mathrm{MNA}, \triangle: \mathrm{I}_{\mathrm{c}}-\mathrm{MNA}$

的弾性率の温度特性を測定し, 図 6 に示した。弾性率の低下し始 める温度を $T_{\mathrm{g}}$ とすれば表 3 にまとめたように, Epon 828 の含 量が多いほど $T_{\mathrm{g}}$ は低温側にシフトし，ビスキナゾロンフェノー ルの導入はビスフェノール Aにくらべて主鎖の剛直性に寄与して いることが示される。

また，この混合系の硬化物の DSC サーモグラムから求めたガ ラス転移温度でもまったく一致した傾向がみとめられ，その組成 と $T_{\mathrm{g}}$ の関係を図 7 に示した。

$\mathrm{N}_{\mathrm{a}}, \mathrm{N}_{\mathrm{b}}, \mathrm{N}_{\mathrm{c}}$ および Epon 828 の NMA 硬化物を空気中で加 熱 $\left(225^{\circ} \mathrm{C}\right)$ したときの重量減少は図 8 に示すよ5に, $\mathrm{N}_{\mathrm{a}}, \mathrm{N}_{\mathrm{b}}$,

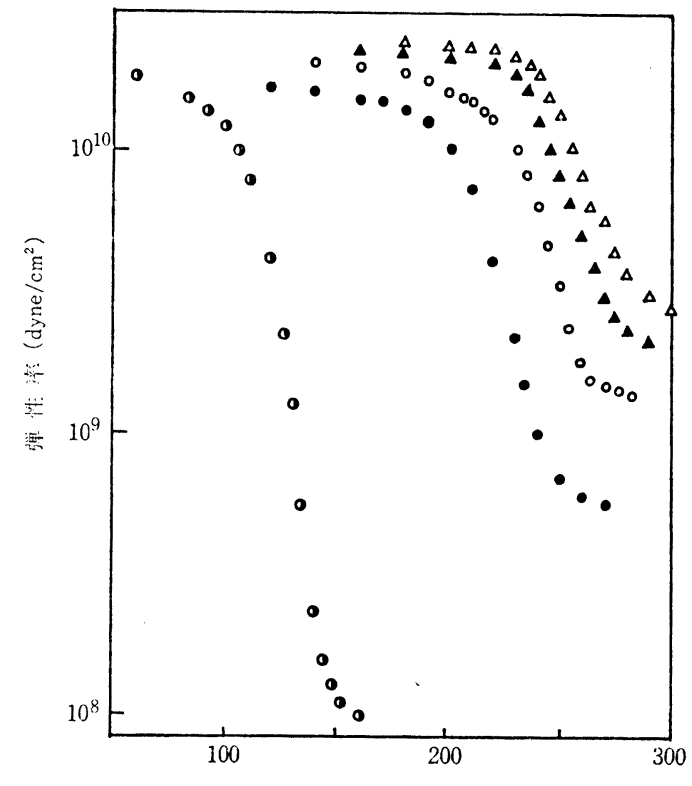

温 度 $\left({ }^{\circ} \mathrm{C}\right)$

図 6 キナゾロンェポキシ樹脂 $\mathrm{N}_{\mathrm{b}}$-Epon 828 系硬化物 の動的弾性率

$\triangle: \mathrm{IV}_{\mathrm{b}}$-Epon 828 重量比 100/0, $\boldsymbol{\Delta}: 75 / 25, \bigcirc: 50 / 50, \bullet: 25 / 75$, D : $0 / 100$, NMA 硬化
表 3 キナゾロンエポキシ樹脂硬化物のガラス転移温度

\begin{tabular}{|c|c|c|c|}
\hline \multicolumn{2}{|c|}{ 硬化物 組 成a) } & \multirow{2}{*}{$\begin{array}{c}T_{\mathrm{g}_{1} \text { b) }} \\
\text { (動的弾性率) } \\
(\text { (C) }\end{array}$} & \multirow{2}{*}{$\begin{array}{c}\left.T_{\mathrm{E}^{2}}{ }^{\mathrm{c}}\right) \\
(\mathrm{DS} \mathrm{S}) \\
\left({ }^{(\mathrm{C})}\right)\end{array}$} \\
\hline $\mathrm{IV}_{\mathrm{b}}$ & Epon 828 & & \\
\hline 100 & 0 & 238 & 220 \\
\hline 75 & 25 & 230 & 209 \\
\hline 50 & 50 & 218 & 188 \\
\hline 25 & 75 & 200 & 165 \\
\hline 0 & 100 & 110 & 91 \\
\hline
\end{tabular}

a) 重量比. 硬化剂は NMA をエポキシ当量 $1 \mathrm{~mol}$ 飞対し $0.8 \mathrm{~mol}$, 助触媒 BDMA $0.5 \%$ を用い, $130^{\circ} \mathrm{C}, 2 \mathrm{hr}, 200^{\circ} \mathrm{C}, 12 \mathrm{hr}$ の硬化条件.

b) ハイブロン, $110 \mathrm{~Hz}, 0.1 \mathrm{~mm}$ 原さ試片.

c) $\mathrm{N}_{2}$ 中, $\Delta T=40^{\circ} \mathrm{C} / \mathrm{min}, 0.1 \mathrm{~mm}$ 厚さ試片.

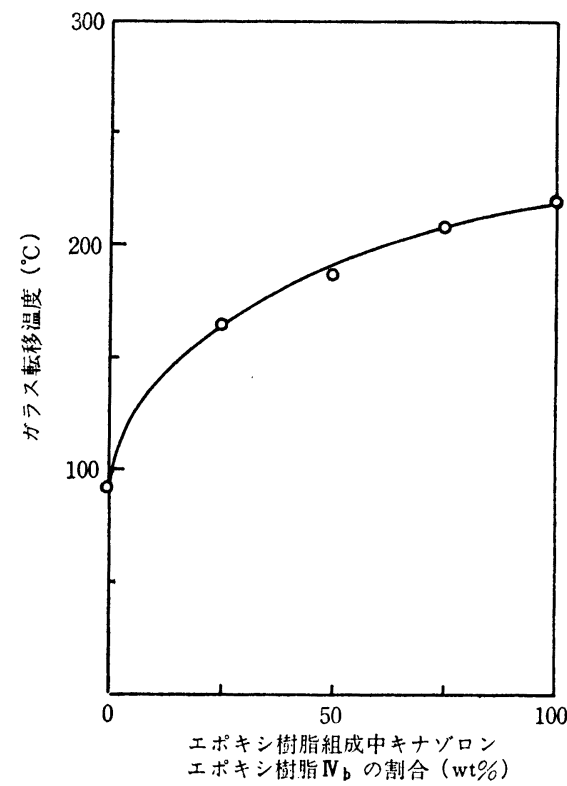

図 7 キナゾロンエポキシ樹脂 $\mathrm{N}_{\mathrm{b}}$-Epon 828 硬化物の 組成とガラス転移温度 $T_{\mathrm{g}}$ (DSC 法) の関係 DSC : $\mathrm{N}_{2}$ 中, $\Delta T=40^{\circ} \mathrm{C} \mathrm{min}$, 試片 $0.1 \mathrm{~mm}$ フィルム

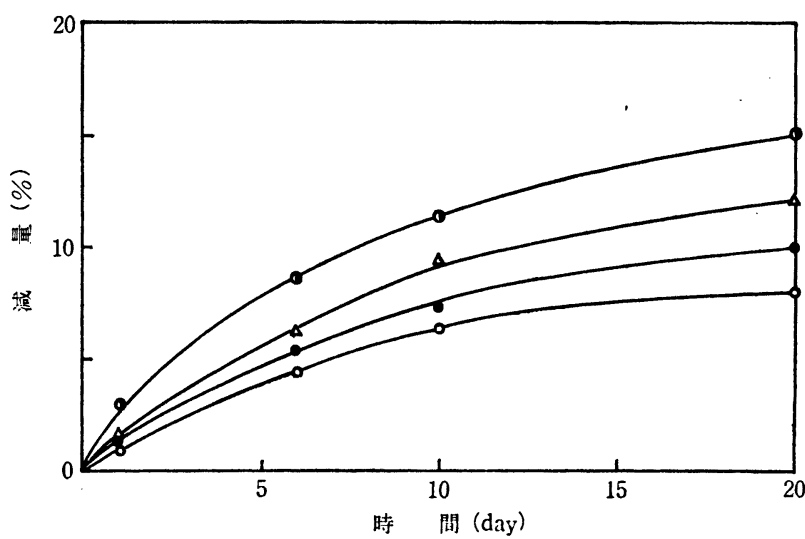

困 8 キナゾロンエポキシ樹脂硬化物の加熱減量 (空気中, $225^{\circ} \mathrm{C}, 0.1 \mathrm{~mm} \times 10 \mathrm{~mm} \times 10 \mathrm{~mm}$ 試价)

$-\mathrm{O}-: \mathrm{NN}_{\mathrm{a}},-\mathbf{-}: \mathrm{N}_{\mathrm{b}},-\triangle-: \mathrm{N}_{\mathrm{c}},-\mathrm{O}-:$ Epon 828 何れも NMA 砸化

$\mathrm{N}_{c}$, Epon 828 の順に減量が大きく, とくにEpon 828 では初期 の減量が大きく, 最初の 6 日間で $N_{a}$ の 2 倍の減量に達する。穻 素雾囲気中での熱重量分析の結果でも，分解開始温度は， $\mathrm{N}_{\mathrm{a}} 300$ ${ }^{\circ} \mathrm{C}, \mathrm{N}_{\mathrm{b}}, \mathrm{N}_{\mathrm{c}} 295^{\circ} \mathrm{C}$, Epon $828290^{\circ} \mathrm{C}$ と大差はないが, $400^{\circ} \mathrm{C}$ に

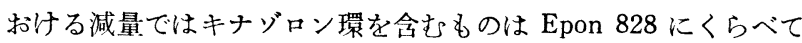
$1 / 2$ 以下の減量を示し, 熱安定性がすぐれている。

$\mathrm{N}_{\mathrm{a}}, \mathrm{N}_{\mathrm{b}}, \mathrm{N}_{\mathrm{c}}$ の硬化物の耐溶剂性はフィルム $(0.1 \mathrm{~mm})$ の状 


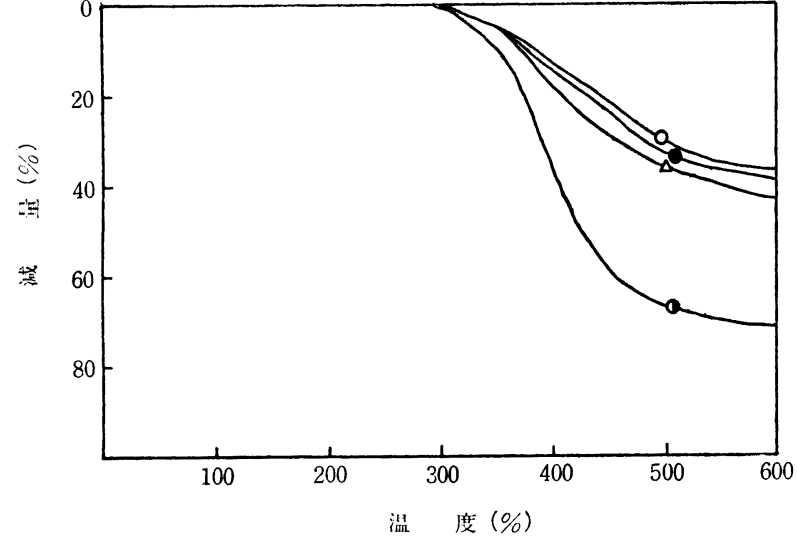

因 9 キナゾロンエポキシ樹脂硬化物の熱重量分析 $\left(\mathrm{N}_{2}\right.$ 中, $0.1 \mathrm{~mm}$ フィルム $10 \mathrm{mg}, \Delta T: 5 \mathrm{C} / \mathrm{min}$ )

$-\mathrm{O}-: \mathrm{IV}_{\mathrm{a}},-\bullet-: \mathrm{N}_{\mathrm{b}},-\triangle-: \mathrm{IV}_{\mathrm{c}},-\mathrm{-}-:$ Epon 828 何れる MNA 硬化
態で，室温 14 日間浸漬した結果，ベンゼン，アセトン，クロロ ホルム, エチルアルコール, 酢酸エチル, m-クレゾール, DMAc, $N$-メチルピロリドン，10\% 硫酸などではほとんど変化はみとめ られなかったが，10\% 水酸化ナトリウム水溶液では脱色がみと められる以外フィルムの可暁性などに変化はみられなく, 耐薬品 性においてもすぐれていることを示した。

以上の結果をまとめて，キナジロン環を導入したジグリシジル エーテルでは芳香族複素環の導入にかかわらず比較的融点は低く， 溶解性もあり, 市肘エポキシ化合物との相溶性をもつが，その硬 化物をビスフェノールA・ジグリシジルェーテル硬化物にくらべ て高い $T_{\mathrm{g}}$ 特よび熱安定性を示し，またこれらビスキナゾロンフ ェノールのパラ, メタ, オルソ体が $T_{\mathrm{g}}$ や熱安定性にも寄与する ことを示した。

（昭和 45 年，日本化学会第 23 年会発表）

\title{
主鎖にアゾ結合を含む高分子金属錯体の合成と熱安定性 ${ }^{* 1, * 2}$
}

\author{
（昭 和 45 年 3 月 30 日 受理）
}

北条舒正・白井汪芳・深津和彥・鈴木 彰*3

\begin{abstract}
$3,3^{\prime}$-ジカルボキシ-4, $4^{\prime}$-ジヒドロキシフゾペンゼン (DDAN) と 1-1'-(p-フェニレン)ビスアゾージー2-ナフトール (PPAN) と

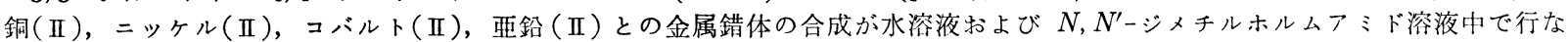
われた。 $\mathrm{pH}$ 滴定曲線, 元素分析, 赤外吸収スペクトルを使って錯体生成を検卻した。すべての金属錯体は金属と配位子が 1 対 1 になった。また DDAN 錯体ではカルボキシル基と水酸基，PPAN 錯体ではアゾ基と水酸基へ配位したキレート棈造を含むるのと 推定される。PPAN の銅（II），コバルト（II），ニッケル（II）錯体のラスト法による分子量はそれでれ 2000，4600，2700で女の

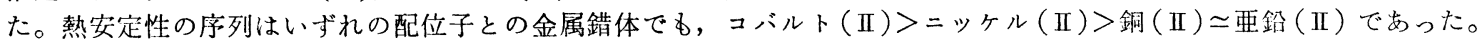

\section{1 緒言}

主鎖に金属を含む高分子金属錯体の合成と熱安定性に関する研 究1 6) の一環として，主鎖にアり゙基を含み，かつ水酸基とカルボ キシル基に配位が生ずると考兄られる $3,3^{\prime}$-ジカルボキシー4, $4^{\prime}$ -

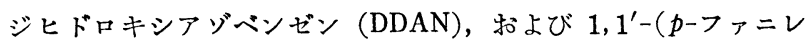
ソビスアゾ)-ジ-2ナフトール (PPAN) の銅(II), ニッケル(II), コバルト（II），亜鉛（II）の遷移金属錯体の合成と熱安定性につ いて以下に述べる実験から検討した。

*1 この報文を「耐熱性ポリマーに関する研究(第 6 報)」とす る.

*2 前報(第 5 報), 北条舒正, 白井汪芳, 鈴木 彰, 工化, 73, 12 月号揭载予定.

*3 Nobumasa Hojo, Hirofusa ShiRaI, Kazuhiko FuKatu, Akira SUZUKI 倍州大学䋐維学部 䋐維工業化学科：長野 県上田市常入.

1）北条舒正，白井汪荕，工化，69，253 (1966).

2) 北条舒正, 白井汪芳, 鉿木 彰, 工化, 72, 2040 (1969).

3）北条舒正, 白井汪芳, 鈴木 彰, 工化, 73, 1438 (1970).

4）北条舒正，白井汪芳，鈴木 彰，工化. 73，2435 (1970).

5）北条舒正, 白井汪芳, 鈴木 彰, 工化. 73,12 月号掲載 予定.
2 実験

$2 \cdot 1$ 試 料

本䒠験で用いた試薬はすべて市肘試薬 1 級品をとのまま用い た。

\section{$2 \cdot 2$ 配 位 子}

2.2・1 3, 3'-ジヒドロキシ-4, 4'-ジカルボキシアソベンゼン (DDAN) Geigy 社の C.I. Mordant Yellow 56) を精製して用 いた。 $\mathrm{Na}$ 塩 $\mathrm{mp} 142^{\circ} \mathrm{C}$ (文献値 ${ }^{7)} 135 \sim 150^{\circ} \mathrm{C}$ )。

$2 \cdot 2 \cdot 2 \quad 1,1^{\prime}-(\boldsymbol{p}-7 \pm$ ニレン)ビスアゾ-ジ-2-ナフトール(PPAN) リン酸 $70 \mathrm{ml} \mathrm{p-フェニレンジアミン} 216 \mathrm{~g}$ を温めながら溶 解し, この溶液を氷と食塩で冷却し，ニトロシル硫酸 $30 \mathrm{ml}$ を $-50^{\circ} \mathrm{C}$ で滴下し， 1 時䦓後過剩の亜硝酸を取り除くため, $2 \mathrm{~g}$ の 尿素を加えた。30 分後過剰の $\beta$ ーナフトールを氷䣫酸に溶解し， 加えた。45 分後, 水水中に混合物を注ぎ, それをロ過した。 $0^{\circ} \mathrm{C}$ に冷却した炭酸カリウム溶液に口過物を溶解し $\beta$-ナフトールと 2 回目のカップリングを行なった。2 時間後, アゾ化合物を口過 し， 2 規定のカ七イカリで洗浄し，生成物を沸騰アニリンから再 結晶した。収率 $85 \%$

6) U.S.P., 1157169 (1945) 